\title{
Ontogeny of Atrial Natriuretic Factor Receptors and Cyclic GMP Response in Rabbit Renal Glomeruli
}

\author{
ROBERT CASTRO, ROSEMARY D. LEAKE, M. GORE ERVIN, MICHAEL G. ROSS, AND \\ DELBERT A. FISHER \\ Perinatal Research Laboratories, Departments of Pediatrics and Obstetrics and Gynecology, UCLA School of \\ Medicine, Harbor-UCLA Medical Center, Torrance, California 90509
}

\begin{abstract}
Atrial natriuretic factor (ANF) has been identified in fetal and newborn mammals, and considerable data regarding fetal ANF metabolism are available. However, there is limited information concerning ANF receptors or receptor ontogenesis in developing mammals. We measured ANF receptor binding capacity, affinity, and ANF-induced cyclic GMP (cGMP) generation in isolated renal glomeruli from fetal $(29 \mathrm{~d}$ gestation, term $=31 \mathrm{~d}$ ), newborn ( $3 \mathrm{~d})$, juvenile ( $28 \mathrm{~d}$ ), and adult rabbits. The (mean \pm SEM) glomerular receptor binding capacity values for ANF in fetal and newborn animals $(10 \pm 1$ and $12 \pm 3$ fmol/mg protein) were similar and significantly lower than the values for juvenile and adult animals $(30 \pm 8$ and $74 \pm$ $15 \mathrm{fmol} / \mathrm{mg}$ protein, respectively). In contrast, there were no significant differences in ANF receptor affinity values or dose-dependent increases in ANF-stimulated cGMP generation among the age groups studied. In competition studies, we observed effective displacement of ${ }^{125} \mathrm{I}-\mathrm{A} \mathrm{NF}$ by $\mathrm{C}-\mathrm{ANF}_{4-23}$, a ring-deleted $\mathrm{ANF}$ analogue, in adult, juvenile, and newborn glomeruli; however, C-ANF displaced only about $50 \%$ of the ${ }^{125} \mathrm{I}-\mathrm{ANF}$ in fetal tissue. The addition of C-ANF did not elicit cGMP generation, nor did C-ANF affect ANF-induced cGMP generation in fetal, newborn, or adult glomeruli. These results indicate that 1 ) the ANF receptor-guanylate cyclase system is intact in 29-d fetal rabbit glomeruli, and 2) the ANF-induced cGMP formation is similar in fetal and adult animals, whereas receptor binding capacity is relatively higher in adult glomeruli. These results suggest a higher proportion of nonguanylate cyclase-coupled ANF receptors in the mature rabbit. (Pediatr Res 30: 45-49, 1991)
\end{abstract}

\section{Abbreviations}

\begin{abstract}
ANF, atrial natriuretic factor cGMP, cyclic GMP

$\mathbf{B}_{\max }$, receptor binding capacity $\mathbf{K}_{d}$, receptor affinity
\end{abstract}

ANF is a cardiac hormone with potent natriuretic, diuretic, and vasodilatory actions in adult animals and humans $(1,2)$.

Received October 15, 1990; accepted March 18, 1991.

Correspondence and reprint requests: Delbert A. Fisher, M.D., Harbor-UCLA Medical Center, Walter P. Martin Research Building, 1124 West Carson Street, Torrance, CA 90502.

Supported in part by Grants HD-06335 and HL-40899 from the National Institutes of Child Health and Human Development, National Institutes of Health R.C. is the recipient of a grant from the Robert Wood Johnson Foundation Medical Minority Faculty Development Program.
The actions of ANF are mediated through specific high-affinity receptors located in various tissues, including several renal structures, vascular endothelium, adrenal glomeruli, lungs, CNS, and the placenta (3-9). Autoradiographic studies of radiolabeled ${ }^{125} \mathrm{I}-$ ANF binding have demonstrated a high density of ANF binding sites in renal glomeruli (4). These glomerular ANF receptors have been shown to be functionally coupled to guanylate cyclase; ANF binding increases intracellular cGMP production, the second messenger that mediates most of the biologic effects of ANF (10). A second class of ANF receptors has been described in vascular and kidney tissues. These receptors are not linked to guanylate cyclase and have a suggested role in ANF clearance/ storage from the circulation (11-13). Recently, activation of nonguanylate cyclase-coupled receptors has been found to increase inositol phosphates (14) and inhibit adenylate cyclase activity (15).

Immunoreactive ANF is present in mammalian fetal cardiac tissue early in gestation $(16,17)$, and relatively high ANF concentrations have been reported in the fetal circulation (18). However, the diuretic and natriuretic effects of ANF appear to be obtunded in immature animals relative to adults $(19,20)$. Recently, ANF receptors have been identified in fetal renal structures of the rat, and ANF binding capacity in these structures has been shown to increase with maturation (21-23). Thus, a reduced ANF binding capacity may account for the decreased action of ANF in immature kidneys, and immaturity of the fetal receptor-guanylate cyclase coupling system may contribute to the decreased action. Our study was designed to characterize the ontogenesis of renal glomerular ANF receptor binding and cGMP generation in the developing rabbit.

\section{MATERIALS AND METHODS}

Kidneys were obtained from fetuses at $29 \mathrm{~d}($ term $=31 \mathrm{~d})$ gestation $(n=28)$, newborn rabbits at $3 \mathrm{~d}(n=21)$, juvenile animals at 4 wk of age $(n=6)$, and adult does $(n=6)$ immediately after delivery. Time-dated does $(n=6)$ were anesthesized with i.v. ketamine $(50 \mathrm{mg} / \mathrm{kg})$ and given oxygen $(5 \mathrm{~L} / \mathrm{min})$ by face mask. After s.c. lidocaine (1\%) administration, a midline abdominal incision was made. Fetal rabbits were removed from the uterus and killed immediately by decapitation. After removal of the last fetus, the doe was killed with an administration of pentobarbital $(100 \mathrm{mg} / \mathrm{kg})$. Three-d and 4-wk-old rabbits were anesthesized with an intramuscular injection of ketamine (50 $\mathrm{mg} / \mathrm{kg}$ ) and killed by decapitation.

Rabbit glomeruli were prepared by graded sieving as described by Carrier et al. (3). Each kidney was excised from the renal capsule and dissected longitudinally, and the cortical tissue was minced and homogenized with a tissue grinder. The minced tissue was gently passed through stainless steel sieves with decreasing mesh sizes of 200,125 , and $50 \mu \mathrm{m}$. The glomerular 
preparation was centrifuged (200 $\mathrm{rpm}$ for 3-5 $\mathrm{min}$ ), and the pellet was resuspended in $50 \mathrm{mM}$ Tris- $\mathrm{HCl}$ buffer, $\mathrm{pH} 7.4$. Tubular fragments and blood cells represented $<10 \%$ of the preparation, and unencapsulated glomeruli represented 80 to $85 \%$ of the total glomerular population. Protein concentration was determined using the Bradford method (24) with BSA as the standard. An aliquot of the fresh glomerular membrane preparation was used to assess cGMP production. The remainder was frozen at $-70^{\circ} \mathrm{C}$ until it was used in receptor binding studies.

Radioreceptor assay. Synthetic human ANF ( $\left.\mathrm{ANF}_{99-126}\right)$ (Bachem Inc., Torrance, CA) was iodinated using sodium ${ }^{125}$ iodide and iodogen (25). Iodinated peptide was purified on a Sep-pak C-18 column and eluted with a linear gradient of acetonitrile in $0.1 \%$ tetrafluoroethylene. Radioactivity in $10-\mu \mathrm{L}$ portions of each fraction counted in a gamma counter, identified two peaks of activity. Measurement of sp act (approximately $1000-2000 \mathrm{Ci} / \mathrm{mmol}$, respectively) determined by self-displacement (26) indicated that these peaks represented monoiodinated and diiodinated peptides.

The binding assay was performed in duplicate in $12 \times 75 \mathrm{~mm}$ borosilicate glass tubes. Aliquots (50 $\mu \mathrm{g}$ of protein) of glomerular membranes were incubated for $30 \mathrm{~min}$ at $4^{\circ} \mathrm{C}$ in assay buffer $(50$ $\mathrm{mM}$ Tris- $\mathrm{HCl}$, pH 7.4, $1 \mu \mathrm{M}$ aprotinin, $0.1 \%$ bacitracin, $0.5 \mathrm{mM}$ phenylmethylsulfonyl fluoride, $5 \mathrm{mM} \mathrm{MgCl}, 0.4 \% \mathrm{BSA}$ ) containing ${ }^{125} \mathrm{I}-\mathrm{ANF}(30 \mathrm{pM})$ and increasing concentrations $\left(10^{-13}\right.$ to $10^{-7} \mathrm{M}$ ) of unlabeled ANF in a final volume of $0.5 \mathrm{~mL}$. Separation of the bound and free hormones was achieved by rapid filtration through $0.3 \%$ polyethylenimine-treated Whatman GF/C filters. The filters were washed three times with $3 \mathrm{~mL}$ of $50 \mathrm{mM}$ Tris- $\mathrm{HCl}$ ( $\mathrm{pH} 7.4$ ), allowed to dry, and counted in an LKB gamma counter (LKB Instruments, Gaithersburg, MD). Competition studies also were conducted with increasing concentrations of AVP, angiotensin II, and a ring-deleted ANF analog, C-ANF $4-23$ (Bachem Inc.). Saturation studies were conducted using increasing amounts of ${ }^{125}$ I-ANF (10-400 pM). Specific binding was calculated as the difference between total binding and nonspecific binding determined in similar samples in the presence of excess unlabeled ANF $\left(10^{-6} \mathrm{M}\right)$.

Cyclic nucleotide determinations. Freshly prepared intact glomeruli (100 $\mu \mathrm{g}$ protein) were resuspended in Hanks' balanced salt solution at $\mathrm{pH} 7.4$ and preincubated at $37^{\circ} \mathrm{C}$. Two min after the addition of isobutylmethyxanthine at $0.5 \mathrm{mM}$ final concentration, cGMP production was initiated by the addition of an increasing dose of ANF and/or C-ANF (at $10^{-9}-10^{-7} \mathrm{M}$, final concentration). The reaction was stopped after $5 \mathrm{~min}$ by adding $0.5 \mathrm{~mL}$ trichloroacetic acid $(12 \mathrm{mg} / \mathrm{dL})$. Precipitated protein was sedimented at $2000 \times g$ for 15 min, the supernatant was extracted with ether, and CGMP concentrations were determined by RIA after acetylation (New England Nuclear Corp, Wilmington, DE).

Results are presented as the mean \pm SEM for multiple experiments. Unpaired $t$ test was used to determine statistically significant differences between the two groups at a significance level of $p<0.05$. Competitive binding data were transformed by Scatchard analysis, using the LIGAND program (27).

\section{RESULTS}

Scatchard analysis of representative competitive binding data for ${ }^{125}$ I-ANF binding to glomeruli from rabbit glomerular membranes indicated the presence of a single class of high-affinity binding sites from each age group (Fig. 1). Displacement of labeled ANF (30 pM) with unlabeled ANF was similar in fetal, newborn, juvenile, and adult glomerular membranes (Fig. 2). C$\mathrm{ANF}_{4-23}$ effectively displaced ${ }^{125}$ I-ANF from binding sites in adult, juvenile, and newborn glomeruli. However, only $50 \%$ of the radiolabeled ligand was displaced in fetal tissue by C-ANF (Fig. 2). No displacement of labeled ANF was observed with unrelated compounds, such as AVP or angiotensin II, in any age group.

Table 1 lists the $K_{d}$ and $B_{\max }$ values for $A N F$ at the various developmental stages studied. In both fetal and newborn glomeruli, the $\mathrm{B}_{\max }$ was lower $(p<0.05)$ than in juvenile and adult rabbits. Although the mean fetal $K_{d}$ values tended to be lower, the $K_{d}$ values did not differ statistically among the groups studied.

Glomerular membrane cGMP generation data in response to an increasing dose of ANF and/or C-ANF are shown in Figure 3. Basal glomerular membrane cGMP formation was similar in all rabbit age groups; no differences in ANF-induced cGMP generation were observed. cGMP was not stimulated by C-ANF, and ANF-induced cGMP formation in fetal, newborn, or adult glomeruli was not inhibited by the presence of C-ANF $\left(10^{-6} \mathrm{M}\right)$.

\section{DISCUSSION}

Our results indicate that specific ANF receptors are present on fetal rabbit glomerular membranes at $29 \mathrm{~d}$ gestation (term $=31$ d). In addition, the $B_{\max }$ for ANF binding in glomerular membranes increases 7-fold from the fetal to the adult age group. These results are in agreement with earlier data in rats $(22,23)$. Although ANF binding capacity was age-dependent, there were no differences in cGMP generation among the age groups studied. This observation contradicts the previously reported correlation between ANF binding capacity and cGMP production in vascular (28) and glomerular membranes (29). However, Ballerman et al. (4) and Michel et al. (30) found no change in ANFinduced cGMP production from down-regulated ANF binding sites in salt-loaded rats. Thus, the significance of the observed dissociation of ANF receptor number and guanylate cyclase responsiveness is unclear but may reflect differences in receptor types.

The ANF receptor is a cell surface membrane-bound guanylate cyclase enzyme. Binding of ANF to an extracellular site on the enzyme elicits intracellular production of cGMP as a second messenger (10). The receptor exists in several forms, including a 120 - to $135-\mathrm{kD}$ single protein and a $66-$ to $70-\mathrm{kD}$ truncated form lacking most of the intracellular domain $(11,31)$. The former binds the major circulating form of ANF ( $\left.\mathrm{ANF}_{99-126}\right)$, and binding evokes cGMP production. The truncated receptor accepts a wider range of ANF structures, but ligand binding does not evoke cGMP generation $(30,32)$. The truncated ANF receptor appears to be the predominant receptor in kidneys and is postulated to modulate ANF clearance $(12,32,33)$. However, activation of nonguanylate cyclase-coupled receptors has been reported to induce formation of inositol phosphates (14), possibly regulating calcium mobilization, protein kinase $C$ activity, and inhibition of the adenylate cyclase/cAMP signal transduction system (15). Additional studies are needed to establish which effects will be mediated through the occupancy of each of the ANF receptors.

In the present study, the truncated ANF analogue $\left(\mathrm{C}-\mathrm{ANF}_{4-23}\right)$ bound to renal glomerular membranes in all age groups studied and, as expected, failed to elicit cGMP generation. That C-ANF binds to over $90 \%$ of adult renal ANF binding sites (12) is consistent with our observations and suggests that the majority of glomerular ANF binding sites represent non-cGMP coupled receptors in adults. C-ANF appeared to displace ${ }^{125} \mathrm{I}-$ ANF less readily from fetal glomeruli, although receptor density was substantially less than that in adult tissue. The response of cGMP to ANF in the rabbit glomeruli was similar to results obtained by other investigators $(4,15,28-30)$. Although our data demonstrate the presence of guanylate cyclase-linked receptors in fetal rabbit glomeruli, the maturational increase in $B_{\max }$ in the absence of changes in CGMP generation suggests that the ratio of truncated to CGMP-generating receptors increases with gestation. In support of this hypothesis, Almeida et al. (33) observed a decreased ANF plasma clearance rate in rats in the presence of C-ANF and postulated that truncated receptors are active in ANF binding and clearance. In contrast, we were unable to show an effect of C-ANF on ANF plasma clearance in the early $3 \mathrm{rd}$ trimester ovine fetus (34).

Robillard et al. (20) observed that the 128- to 139-d gestation 


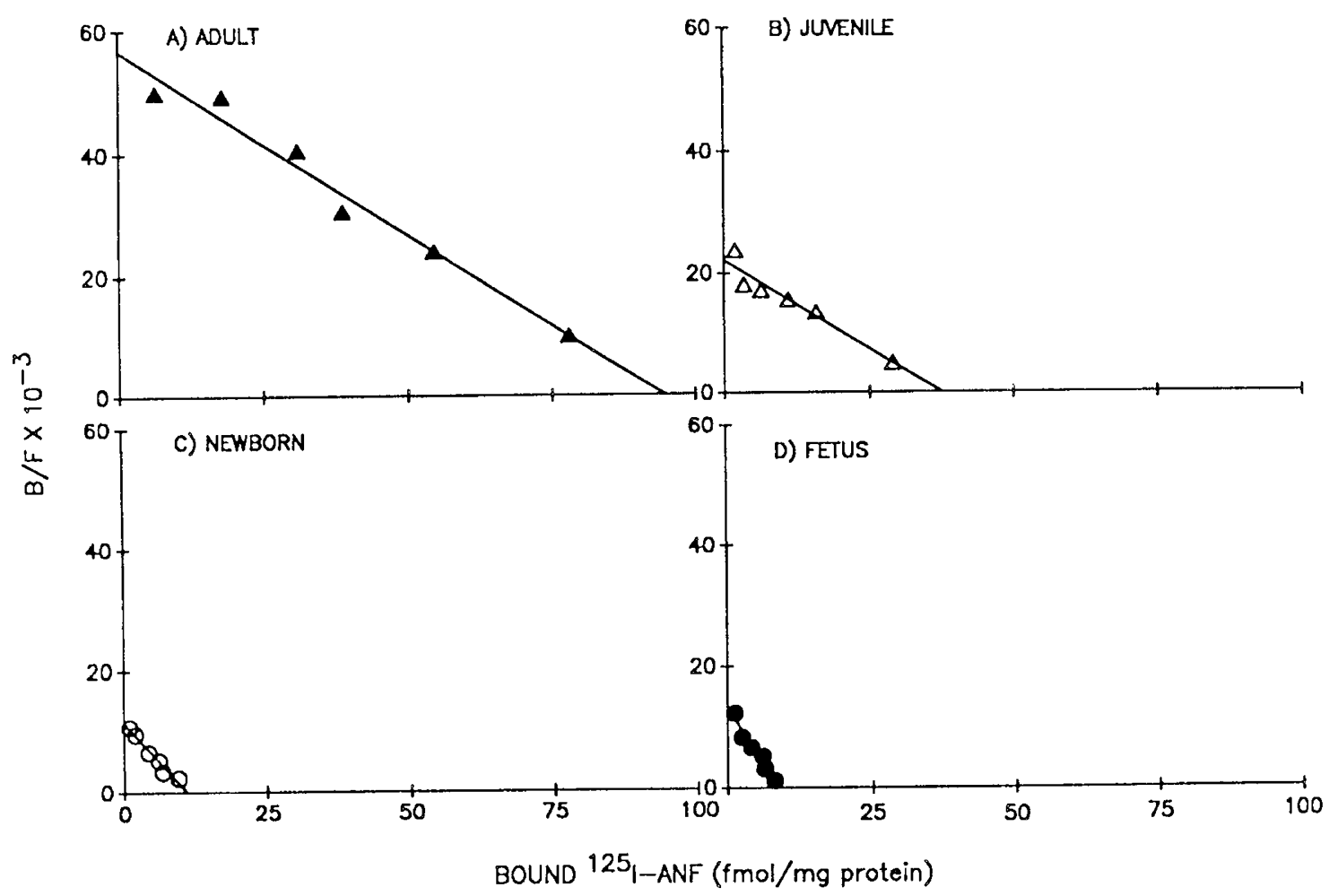

Fig. 1. Scatchard transformation of ${ }^{125} \mathrm{I}$-ANF binding to $A$, adult; $B$, juvenile; $C$, newborn; and $D$, fetal rabbit glomerular membranes.

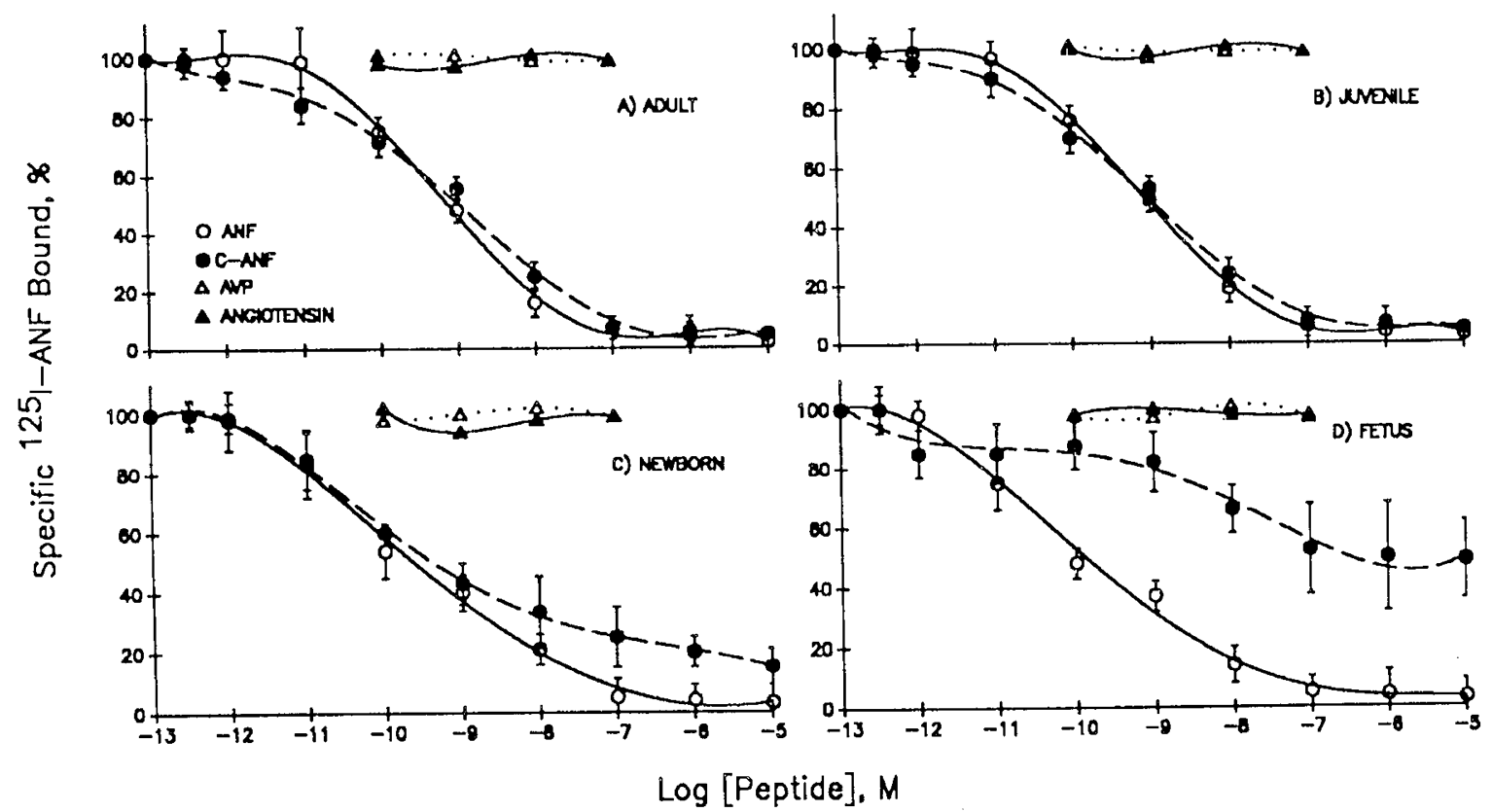

Fig. 2. Competition studies of ${ }^{125} \mathrm{I}$-ANF binding in $A$, adult; $B$, juvenile; $C$, newborn; and $D$, fetal glomerular membranes. Values are plotted as mean \pm SEM of three separate experiments.

Table 1. Rabbit glomerular $A N F K d$ and $B_{\text {max }}$ in developing and adult rabbits

\begin{tabular}{lcc}
\hline & $\begin{array}{c}\mathrm{Kd} \\
(\mathrm{pM})\end{array}$ & $\begin{array}{c}\mathrm{B}_{\max } \\
(\mathrm{fmol} / \mathrm{mg} \text { protein })\end{array}$ \\
\hline Fetus (29 d), $n=28$ & $76 \pm 12$ & $10 \pm 1^{*}$ \\
Newborn $(3 \mathrm{~d}), n=21$ & $174 \pm 52$ & $12 \pm 3^{*}$ \\
Juvenile $(28 \mathrm{~d}), n=6$ & $156 \pm 59$ & $30 \pm 8$ \\
Adult, $n=6$ & $177 \pm 59$ & $74 \pm 15$ \\
\hline
\end{tabular}

$* p<0.05$ vs adult values. ovine fetal kidney is less responsive to ANF than the adult kidney, and we have reported a relatively increased renal responsiveness to ANF in the younger (114-d) ovine fetus versus the near-term (130-d) fetus despite similar ANF plasma levels and clearance values at these fetal ages (35). This age-dependent decrease in response to ANF in the 3rd-trimester fetal sheep suggests developmental regulation of guanylate cyclase-linked receptors in the developing mammal. It is unclear whether the decreased ANF binding capacity in fetal tissue versus adult tissue is due to downregulation of uncoupled receptors or receptor occupation (30) secondary to the relatively high plasma ANF levels found in the fetus $(18,34,35)$. However, nonguanylate-linked receptors ap- 


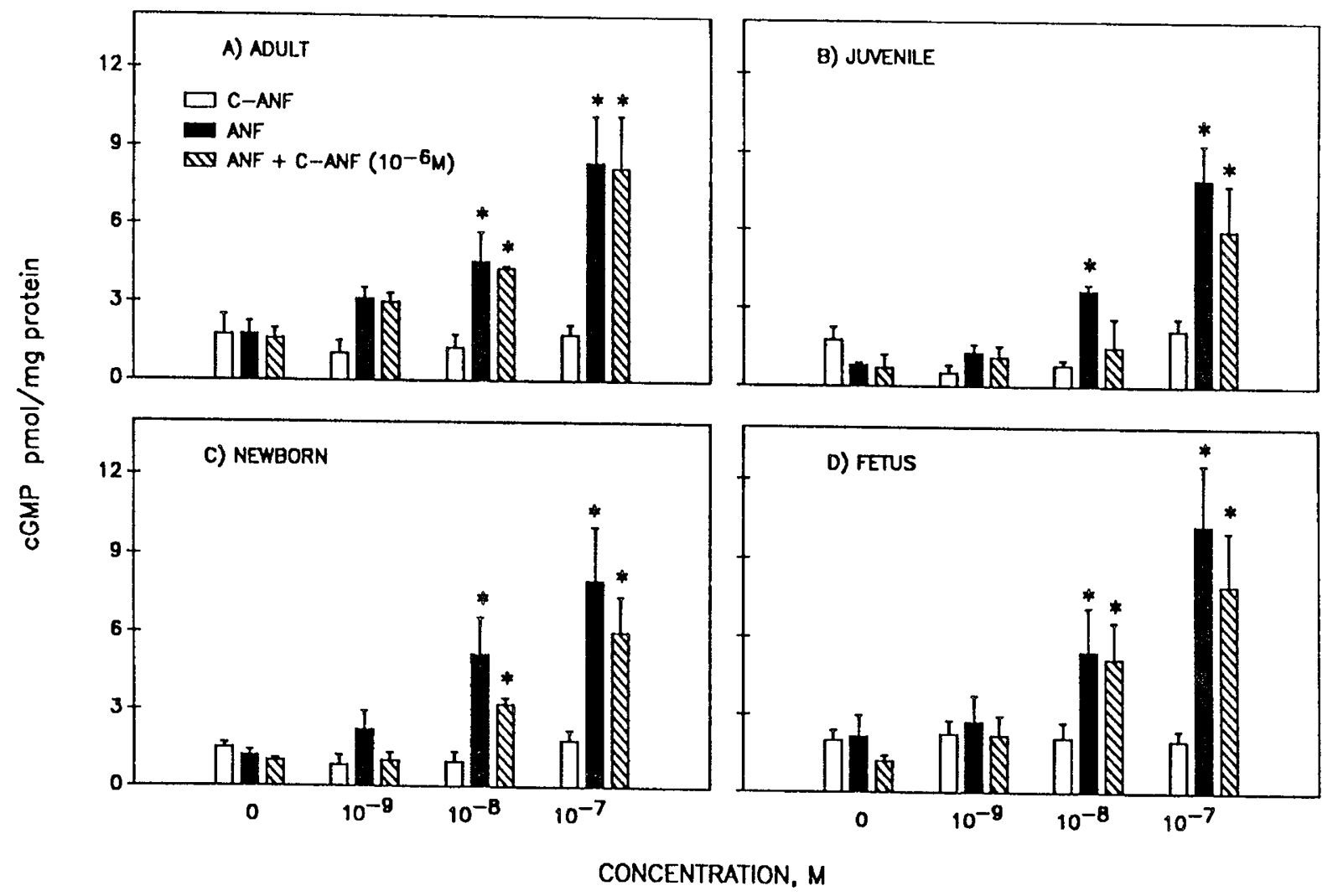

Fig. 3. Dose response of cGMP to increasing concentrations of C-ANF (open bar), ANF (closed bar), and ANF in the presence of $10^{-6} \mathrm{M}$ CANF (hatched bar) in glomeruli from $A$, adult; $B$, juvenile; $C$, newborn; and $D$, fetal rabbit. Values are the mean \pm SEM of three separate
experiments. ${ }^{*}, p<0.05$ vs control values.

pear to be more sensitive to down-regulation in response to volume and sodium fluctuations or prolonged exposure to high concentrations of ANF $(28,30)$.

The correlation of functional ANF receptors and biologic responses in developing target tissues and intact animals remains unclear. Nakazawa et al. (36) demonstrated that ANF decreased cardiac output and arterial pressure in the chick embryo (stage 21), and Balaraman et al. (37) observed no difference in ANFinduced aortic ring relaxation in guinea pig fetuses at $55-60 \mathrm{~d}$ gestation (term $=68 \mathrm{~d}$ ) relative to adults. In addition, Schiffrin et al. (38) observed similar ANF-induced relaxation in precontracted vascular tissue in both young (4-8 wk) and older (16 wk) rats, despite a significant reduction in ANF binding sites in the younger animals. Thus, despite in vitro evidence for functional renal and vascular ANF receptors, in vivo systemic ANF infusion studies in rats (19) and sheep (20) indicate blunted renal and cardiovascular responses to ANF in immature animals when compared with adults. In addition, Chevalier et al. (39) observed that in young rats, ANF-induced urinary cGMP and sodium excretion do not correlate, suggesting that cGMP may not adequately reflect the renal action of ANF. Although the mechanism(s) for the differences between the in vitro and in vivo responses to ANF is not clear, ANF metabolic clearance, altered hemodynamics, and neurohumoral reflexes all may contribute in intact, immature animals. For example, despite in vitro evidence of a relatively decreased abundance of clearance receptors in the developing kidney, plasma ANF clearances are higher in fetal than in adult sheep (40), suggesting that additional clearance site(s) or mechanisms (i.e. placental metabolism) may account for the diminished fetal action of ANF (35). In addition, lower systemic perfusion pressure and decreased organ blood flow may minimize or preclude ANF-induced cardiovascular or renal effects in the immature animal.

In summary, we have demonstrated that fetal rabbit glomeruli manifest high-affinity and low-capacity ANF binding consistent with an ANF receptor. The associated dose-dependent increases in cGMP production are consistent with the presence of a guanylate cyclase-linked receptor population. Of special interest was our observation that, despite increases in glomeruli ANF receptor numbers with maturation, cGMP generation remained unchanged. The developmental changes in receptor density without differences in receptor responsiveness suggest that the enhanced renal response to ANF with maturation is not receptormediated or guanylate cyclase-dependent. In turn, formation or inhibition of second messengers other than cGMP through ANF receptor subtype(s) occupancy may differ with maturation. Future studies investigating the presence, characteristics, and density of ANF receptor types in developing target organs during maturation will better define the physiologic role of ANF in developing mammals.

Acknowledgments. The authors thank Glenda Calvario, Lisa Miller, and Jim Humme for their assistance in the completion of these studies and Sharon Schuler for her assistance in the preparation of the manuscript.

\section{REFERENCES}

1. Cantin M, Genest $J 1985$ The heart and the atrial natriuretic factor. Endocr Rev 6:107-127

2. Debold AJ 1985 Atrial natriuretic factor: a hormone produced by the heart. Science 230:767-770

3. Carrier F, Thibault G, Schiffrin EL, Garcia R, Gutkowska J, Cantin M, Genest J 1985 Partial characterization and solubilization of receptors for atrial natriuretic factor in rat glomeruli. Biochem Biophys Res Commun 132:666-

4. Ballerman BI, Hoover RL, Karnowsky MJ, Brenner BM 1985 Physiological regulation of atrial natriuretic peptide receptors in rat renal glomeruli. J Clin
Invest 76:2049-2056

5. Schiffrin EL, Chartier L, Thibault G, St-Louis J, Cantin M, Genest J 1985 Vascular and adrenal receptors for atrial natriuretic factor in the rat. Circ
Res 56:801-807

6. Turrin M, Gillis N 1986 Removal of atrial natriuretic peptide by perfused rabbit lungs in situ. Biochem Biophys Res Commun 140:868-873 
7. Mantyh CR, Kruger L, Brecha NC, Mantyh PW 1986 Localization of specific binding sites for atrial natriuretic factor in peripheral tissues of the guinea pig, rat and human. Hypertension 8:712-721

8. Quirion R, Dolpe M, Dam TV 1986 Characterization and distribution of receptors for the atrial natriuretic peptides in mammalian brain. Proc Nat Acad Sci USA 83:174-178

9. Hatjis GC, Grogans DM 1988 Atrial natriuretic peptide receptors in normal human placentas. Am J Obstet Gynecol 159:587-591

10. Hamet P, Tremblay J, Pang SC, Garcia R, Thibault G, Gutkowska J, Cantin M, Genest J 1984 Effect of native and synthetic atrial natriuretic factor on cyclic GMP. Biochem Biophys Res Commun 123:515-527

11. Takayanagi R, Snajdar RM, Imada T, Tamura M, Pandy KN, Misono KS Inagami T 1987 Purification and characterization of two types of atria natriuretic factor receptors from bovine adrenal cortex: guanylate cyclaselinked and cyclase-free receptors. Biochem Biophys Res Commun 144:244 250

12. Maack T, Suzuki M, Almeida FA, Nussenzveig D, Scarborough RM, McEnroe GA, Lewicki JA 1987 Physiological role of silent receptors of atrial natriuretic factor. Science 238:675-678

13. Porter JG, Scarborough RM, Wank Y, Schenk D, McEnroe GA, Kang LL Lewicki JA 1989 Recombinant expression of a secreted form of the atrial natriuretic peptide clearance receptor. J Biol Chem 264:14179-14184

14. Hirata M, Chang CH, Murad F 1989 Stimulatory effects of atrial natriuretic factor on phosphoinositide hydrolysis in cultured bovine aortic smooth muscle cells. Biochim Biophys 1010:346-351

15. Anand-Srivastava MB, Sairam MR, Cantin M 1990 Ring-deleted analogs of atrial natriuretic factor inhibit adenylate cyclase/cAMP system. J Biol Chem 265:8566-8572

16. Dolan LM, Dobrozsi DJ 1987 Atrial natriuretic polypeptide in the fetal rat: ontogeny and characterization. Pediatr Res 22:1572-1573

17. Castro R, Polk DH, Lam RW, Leake RD, Fisher DA 1988 Atrial natriuretic factor: developmental changes in the ovine fetus. Pediatr Res 23:239A(abstr)

18. Ross MG, Ervin MG, Lam RW, Castro L, Leake RD, Fisher DA 1987 Plasma atrial natriuretic peptide response to volume expansion in the ovine fetus. Am J Obstet Gynecol 157:1292-1297

19. Chevalier RL, Gomez RA, Carey RM, Peach MJ, Linden JM 1988 Renal effects of atrial natriuretic peptide infusion in young and adult rats. Pediatr Res 24:333-337

20. Robillard JE, Nakamura KT, Varille VV, Andersen AA, Matherne GP, Vanorden DE 1988 Ontogeny of the renal response to natriuretic peptide in sheep. Am J Physiol 254:F634-F641

21. Scott JN, Jennes LH 1989 Ontogeny of atrial natriuretic peptide receptors in fetal rat kidney and adrenal gland. Histochemistry 91:395-400

22. Ogura T, Yamamoto I, Ogawa N 1989 Developmental change of kidney receptor for atrial natriuretic factor in spontaneously hypertensive rat. Hypertension 13:449-455

23. Semmekrot B, Roseau S, Vassent G, Butlen D 1990 Developmental patterns of renal atrial natriuretic receptors: [ ${ }^{125}$ I] alpha-rat atrial natriuretic peptide binding in glomeruli and inner medullary collecting tubules microdissected from kidneys of young rat. Mol Cell Endocrinol 68:35-43
24. Bradford MM 1976 A rapid and sensitive method for the quantitation of microgram quantities of protein utilizing the principle of protein-dye binding. Anal Biochem 72:248-254

25. Franker PJ, Speck JC 1978 Protein and cell membrane iodinations with sparingly soluble chloromide, 1,3,4,6-tetra chloro 3a,6a-diphenylglycoluril. Biochem Biophys Res Commun 80:849-857

26. Pandian MR, Lam RW, Castro L, Fisher DA 1986 Radioimmunoassay for atrial natriuretic peptide using amino terminal reactive antibody. Clin Chem 32:1071(abstr)

27. Munson PJ, Rodbard D 1980 LIGAND: a versatile computerized approach for characterization of ligand binding system. Anal Biochem 107:220-239

28. Roubert P, Lonchampt MO, Chabrier PE, Plas P, Goulin J, Braquet J 198 Down regulation of atrial natriuretic factor receptors and correlation with cGMP stimulation in rat cultured vascular smooth muscle cells. Biochem Biophys Res Commun 143:61-67

29. Tremblay J, Gerzer R, Vinay P, Pang SC, Beliveau R, Hamet P 1984 The increase of $\mathrm{CGMP}$ by atrial natriuretic factor correlated with the distribution of particulate guanylate cyclase. FEBS Lett 181:17-22

30. Michel H, Meyer-Lihnert H, Backer A, Stelkens H, Kramer HJ 1990 Regulation of atrial natriuretic peptide receptors in glomeruli during chronic salt loading. Kidney Int 38:73-79

31. Pandy KN, Pavlou SN, Inagami T 1988 Identification and characterization of three distinct atrial natriuretic factor receptors. J Biol Chem 263:1340613413

32. Nussenzveig D, Scarborough RM, Lewicki JA, Maack T 1989 Clearance receptors of atrial natriuretic factor in isolated glomeruli and mesangial cells in culture. Proc Ann Meet Am Soc Nephrol 20:32(abstr)

33. Almeida FA, Suzuki M, Scarborough RM, Lewicki JA, Maack T 1989 Clearance function of type $\mathrm{C}$ receptors of atrial natriuretic factor in rats. Am J Physiol 256:R469-R475

34. Castro R, Ervin MG, Leake RD, Ross MG, Fisher DA 1991 Effect of a ring deleted atrial natriuretic factor analogue on ovine fetal renal function. Pediat Res 29:342-346

35. Castro R, Ervin MG, Leake RD, Ross MG, Sherman DJ, Fisher DA 199 Fetal renal response to atrial natriuretic factor decreases with maturation. Am J Physiol 260:R346-R352

36. Nakazawa M, Kajio F, Ikeda K, Takao A 1990 Effect of atrial natriuretic peptide on hemodynamics of the stage 21 chick embryo. Pediatr Res 27:557560

37. Balaraman V, Kullama LK, Easa D, Robillard JE, Hashiro GM, Nakamura KT 1990 Developmental changes in sodium nitroprusside and atrial natriuretic factor mediated relaxation in the guinea pig aorta. Pediatr Res 27:392395

38. Schiffrin EL, St-Louis J, Garcia R 1988 Vascular receptors for atrial natriuretic peptide in spontaneously hypertensive rats. Am J Hypertens 1:114A(abstr)

39. Chevalier RL, Thornhill B, Gomez RA, Ragsdale NV, Peach MJ, Carey RM 1990 Role of atrial natriuretic peptide in the response to blood volume expansion in the weanling rat. Pediatr Res 27:396-400

40. Ervin MG, Ross MG, Castro R, Sherman D, Lam RW, Castro L, Leake RD, Fisher DA 1988 Ovine fetal and adult atrial natriuretic factor metabolism. Am J Physiol 254:R40-R46 